\title{
PD-1 and PD-L2: Do they have prognostic value in lymphomas?
}

\section{PD-1 ve PD-L2: Lenfomalarda prognostik değeri var mı?}

\author{
Serdal Korkmaz, Selahattin Erdem², Ebru Akay3, Erdem Arzu Taşdemir³, Hatice Karaman \\ Muzaffer Kekliki ${ }^{1}$
}

${ }^{1}$ Kayseri Training and Research Hospital, Department of Hematology, Kayseri, Turkey

2 Kayseri Training and Research Hospital, Department of Internal Medicine, Kayseri, Turkey

${ }^{3}$ Kayseri Training and Research Hospital, Department of Pathology, Kayseri, Turkey

Corresponding author: Serdal Korkmaz, MD, Kayseri Training and Research Hospital, Department of Hematology, Kayseri, Turkey

E-mail: baranserdalkorkmaz@gmail.com

Received/Accepted: November 05, 2019 /June 21, 2021

Conflict of interest: There is not a conflict of interest.

\section{SUMMARY}

Objective: PD-1 (programmed death-1) is an immune checkpoint receptor that modulates $\mathrm{T}$-cell activity in peripheral tissues via interaction with its ligands, PD-L1 (programmed death-ligand 1) and PD-L2 (programmed death-ligand 2). Tumor cells upregulate PD-L1 or PD-L2 to dampen T lymphocyte attack. The checkpoint inhibition by tumor cells via the PD-1 pathway suppress the antitumor immune response. The role of PD-1 pathway has been extensively investigated in non-hematologic malignancies, however, the exact role of this pathway is not established in hematologic disorders. So, we aimed to demostrate the PD-1 and PD-L2 expresion rate of various lymphoma subtypes, and to evaluate whether PD1 and PD-L2 expresion have impact on prognosis.

Method: For this purpose, pre-treatment lymph node biopsy specimens of 92 patients [25 Hodgkin lymphoma (HL) and 67 non-Hodgkin lymphoma (NHL)] have been stained with monoclonal antibody immunstains of PD-1 and PD-L2.

Results: The overall expression rate of PD- 1 was $76 \%$ and $82.1 \%$ in patients with HL and NHL, respectively. PD-L2 expression rate was weak in both HL and NHL cases. Since we have evaluated whether there is a correlation between immunohistochemistry (IHC) results and survival of patients with HL and NHL, we couldn't demonstrate a meaningful evidence that these markers have an impact on prognosis.

Conclusions: We conclude that the role of PD-1 pathway can be demonstrated by IHC. If IHC markers might be standardized in the future, especially a cutoff that defines a clinically significant positive and predictive value, may help identifying patients more likely to benefit from anti-PD-1 therapies.

Keywords: PD-1, PD-L2, immunohistochemistry, hodgkin lymphoma, non-hodgkin lymphoma, prognosis

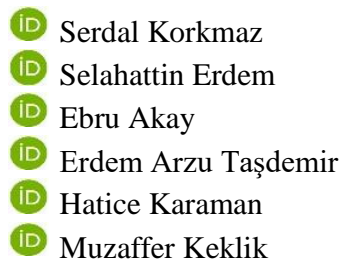

ORCID IDs of the authors: S.K. 0000-0002-5759-2735 S.E. $0000-0001-7804-9582$ E.A. $0000-0003-1190-1800$ E.A.T. $0000-0002-5183-6663$ H.K. 0000-0002-5250-5663 M.K. 0000-0002-6426-5249

\section{ÖZET}

Amaç: PD-1 (programlanmış ölüm-1), ligandları, PD-L1 (programlanmış ölüm-ligand1 1) ve PD-L2 (programlanmış ölüm-ligand 2 2) ile etkileșim yoluyla periferik dokulardaki T-hücresi aktivitesini modüle eden bir bağışıklık kontrol noktası reseptörüdür. Tümör hücreleri, T lenfosit saldırısını azaltmak için PD-L1 veya PD-L2'yi upregüle eder. Tümör hücreleri tarafından PD-1 yolak üzerinden kontrol noktası inhibisyonu, antitümör immün tepkisini bastırır. PD-1 yolunun 
rolü hematolojik olmayan malignitelerde kapsamlı bir şekilde araştırılmıştır, ancak bu yolun tam rolü hematolojik bozukluklarda belirlenmemiştir. Bu nedenle, çeşitli lenfoma alt tiplerinin PD-1 ve PD-L2 ekspresyon oranlarını göstermeyi ve PD-1 ve PD-L2 ekspresyonunun prognoza etkisinin olup olmadığını değerlendirmeyi amaçladık.

Yöntem: Bu amaçla 92 hastanın [25 Hodgkin lenfoma (HL) ve 67 Hodgkin olmayan lenfoma (NHL)] tedavi öncesi lenf nodu biyopsi örnekleri monoklonal PD-1 ve PD-L2'nin antikor immün boyaları ile boyanmıștır.

Bulgular: PD-1'in genel ekspresyon oran1, HL ve NHL'li hastalarda sırasıla \%76 ve \%82.1 idi. PD-L2 ekspresyon oran1 hem HL hem de NHL vakalarında zayıftı. İmmünohistokimya (IHC) sonuçları ile HL ve NHL'li hastaların sağkalımı arasında bir korelasyon olup olmadığını değerlendirdiğimiz için, bu belirteçlerin prognoz üzerinde bir etkisi olduğuna dair anlamlı bir kanıt gösteremedik.

Sonuç: PD-1 yolak rolünün IHC tarafından gösterilebileceği sonucuna vardık. IHC belirteçleri gelecekte standardize edilebilirse, özellikle klinik olarak anlamlı bir pozitif ve prediktif değeri tanımlayan bir sınır değer, anti-PD-1 tedavilerinden yararlanma olasılığı daha yüksek olan hastaların belirlenmesine yardımcı olabilir.

Anahtar sözcükkler: PD-1, PD-L2, immünohistokimya, hodgkin lenfoma, non-hodgkin lenfoma, prognoz

\section{INTRODUCTION}

The PD-1 / PD-L1 (programmed death-1 / programmed death-ligand 1) pathway has led to major breakthroughs in the cancer immunotherapy field. PD-1 is an immune checkpoint receptor that modulates T-cell activity in peripheral tissues via interaction with its ligands, PD-L1 and PD-L2 (programmed death-ligand 2). PD-1 is expressed on activated $\mathrm{T}$ cells, $\mathrm{B}$ cells, and myeloid cells. Binding of PD-1 to its ligands limits effector T-cell activity, and therefore regulating detrimental immune responses and preventing autoimmunity ${ }^{1}$. Upon antigen recognition, activated $\mathrm{T}$ cells express PD-1 on their surface and produce interferons that lead to the expression of PD-L1 in multiple tissues, including cancer ${ }^{2}$. In progress, PD-L1 induces a coinhibitory signal in activated $\mathrm{T}$-cells and promotes T-cell apoptosis, T-cell anergy and T-cell functional exhaustion ${ }^{3,4}$.

Expression of PD-L1 and PD-L2, has been identified both on tumor cells and within the tumor microenvironment. Various tumour types such as breast cancer, gastric cancer, melanoma, and nonsmall-cell lung cancer, are able to express PD-L1 ${ }^{5}$. Yamamoto et al. showed that the malignant ReedSternberg cells in Hodgkin lymphoma (HL) expressed large amounts of PD-L1, and were surrounded by functionally impaired PD-1 positive T cells ${ }^{6}$. Among other haematologic malignancies, some non-Hodgkin lymphoma (NHL) subtypes which frequently express PD-L1 include adult Tcell leukaemia lymphoma and angioimmunoblastic T-cell lymphoma ${ }^{7-10}$. Less is known about PD-L2, which is expressed on dendritic cells, macrophages, mast cells and B cells ${ }^{11}$. In tumours, PD-L2 is overexpressed in B cell lymphomas such as primary mediastinal B-cell lymphoma, follicular B-cell lymphoma (FL) and HL ${ }^{12}$.

Until now, the role of PD-1 pathway has been extensively investigated in non-hematologic malignancies, and upon understanding the importance of this pathway, anti-PD-1 therapeutic strategies have been developed to treat solid malignancies. However, the exact role of this pathway is not known in hematologic disorders, and it is being newly analyzed. In the literature, there are reports in limited numbers regarding the effectiveness of anti-PD-1 agents in hematologic malignancies, so this a new area to be solved in near future. So, the goal of this study was to demostrate the PD-1 and PD-L2 expresion rate of various lymphoma subtypes, and to evaluate whether PD-1 and PD-L2 expresion have impact on prognosis. For this purpose, the lymph node biopsy specimens of 92 patients with HL and NHL have been stained with monoclonal antibody immunstains of PD-1 and PD-L2.

\section{MATERIAL AND METHODS}

The study was conducted in a retrospective manner in a tertiary unit in Turkey. The departments of Hematology and Pathology have contributed to this study. The patients, who are alive and/or if dead their relatives, have provided their written informed consent for the participation. The study was approved by the local Ethics Committees and was in accordance with the Declaration of Helsinki.

A total of 92 patients with lymphomas were enrolled in the study. Medical records of patients diagnosed between the time period of January 2011 and January 2016 were collected, retrospectively. The diagnostic lymph node biopsy specimens of 92 patients were found by the archieve of pathology. Briefly, tissues were fixed in $10 \%$ buffered formalin and paraffin-embedded. One paraffinembedded block tissue was selected for each case and were cut into 4 micron sections. Tissue sections were deparaffinized by xylene and rehydrated with ethanol. Sections were incubated with commercially available mouse anti-human antibodies of PD-1 (NAT 105)(Ventana catalog number: 760-4895) and PD-L2 (Anti-NeuN antibody; 1B7, ty25 ab)(Catalog number: 21107). 
Immunohistochemical staining was examined by using avidin-biotin-peroxidase method.

Each specimen was evaluated independently by 2 pathologists by polarized light microscopy. For each case, the section with the highest percentage of tumor cells stained was used for analysis. Namely, besides intensity, the tumor infiltration pattern was also annotated. Positive (lymph node T cells) and negative IHC controls were routinely used. The intensity of immunohistochemical staining with PD-1, which were observed in membrane and/or cytoplasm of immune cells, was scored by a 4-point scale. Score ' 0 ' meant minimal membrane staining with PD-1 in less than $1 \%$ of immune cells, or no staining with PD-1 was identified. Score ' 1 ' $(1+)$ indicated minimal to moderate membrane staining with PD-1 in between $1 \%$ to $20 \%$ immune cells. Score ' 2 ' $(2+)$ indicated moderate to high membrane staining with PD-1 in between $20 \%$ to $50 \%$ immune cells. Score ' 3 ' (3+) indicated the highest membrane staining with PD$1 \geq 50 \%$ of immune cells. Similarly, the intensity of immunohistochemical staining with PD-L2 was scored by a 4-point scale. Score ' 0 ' meant minimal membrane staining with PD-L2 in less than $1 \%$ tumor cells, or no staining with PD-L2 was identified. Score ' 1 ' $(1+)$ indicated minimal to moderate membrane staining with PD-L2 in between $1 \%$ to $20 \%$ tumor cells. Score ' 2 ' $(2+)$ indicated moderate to high membrane staining with PD-L2 in between $20 \%$ to $50 \%$ tumor cells. Score ' 3 ' (3+) indicated the highest membrane staining with PD-L2 $\geq 50 \%$ of tumor cells.

\section{Statistical Analysis}

All statistical analyses were performed using SPSS version 21.0 (SPSS, Chicago, IL, USA). Descriptive statistics were calculated for each of the variables. Data were expressed as medians and percentages. Overall survival (OS) time was calculated from the date of diagnosis to the date of death or last follow-up. Distribution differences of clinical characteristics between groups were analyzed with Pearson Chi-square and survival curves were estimated with the Kaplan-Meier method, groups were compared using the log-rank test. All $\mathrm{P}$ values were 2 sided, and values were regarded statistically significant if $\mathrm{P}<.05$.

\section{RESULTS}

A total of 92 cases with lymphoma [25 (27.2\%) HL, 67 (72.8\%) NHL] were evaluated. The median age of the patients with HL and NHL was 38 and 65 years, respectively. The laboratory and clinical characteristics of the patients are exhibited in table 1 .

Nodular sclerosing subtype (68\%) was the most frequent subtype in HL group. The patients with $\mathrm{HL}$ had received ABVD (Adriamycin + Bleomycin + Vinblastine + Dacarbazine) as a standard chemotherapy regimen, and NHL patients had received chemotherapy regimens according to their lymphoma subtypes. Mostly was R+CHOP (Rituximab + Cyclophosphamide + Doxorubicin + Vincristine + Prednisolone), beacause diffuse large B cell lymphoma (DLBCL) $(80.6 \%)$ was the most frequent subtype in NHL group.

The overall expression rate of PD-1 was $76 \%$ and $82.1 \%$ in patients with HL and NHL, respectively. PD-L2 expression rate was weak in both HL and NHL cases. Figures 1 and 2 are demonstrative examples showing immunostaining of PD-1 and PD-L2. A summary of immunohistochemistry (IHC) stain results are summarized in table 1. Also, the distribution of cases according to PD-1 and PDL2 immunostaining results of lymphoma subtypes were displayed in table 2 . 


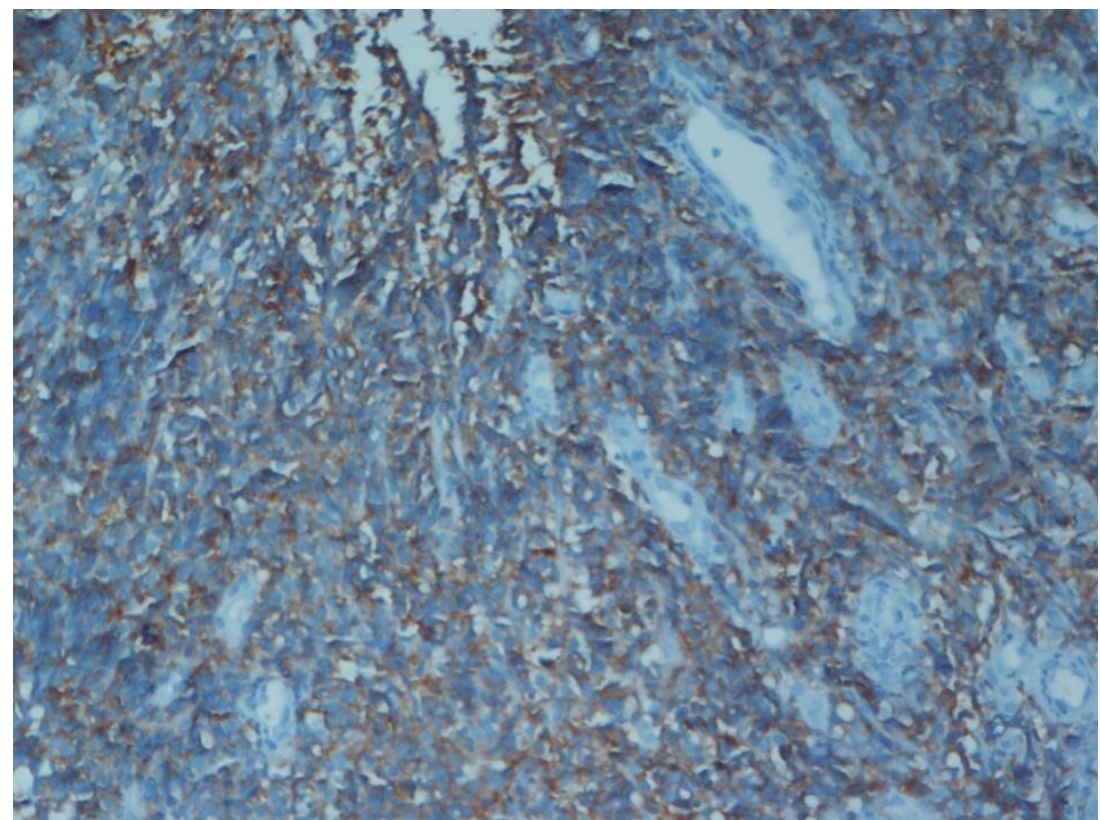

Fig 1: A representative image showing 3+ cytoplasmic-membranous staining of PD-1 antibody (original magnification, $\mathrm{x} 10$ )

Table 2: Distribution of cases according to PD-1 and PD-L2 immunostaining results of lymphoma subtypes

\begin{tabular}{|c|c|c|c|c|c|c|c|c|}
\hline \multirow{2}{*}{ Lymphoma and subtypes } & \multicolumn{4}{|c|}{ PD-1 expression rate } & \multicolumn{4}{|c|}{ PD-L2 expression rate } \\
\hline & $\mathbf{0}$ & 1 & 2 & 3 & $\mathbf{0}$ & 1 & 2 & 3 \\
\hline \multicolumn{9}{|l|}{ Hodgkin Lymphoma } \\
\hline NSHL (n, \%) & & & & & & & & \\
\hline MCHL (n, \%) & $5(29)$ & $8(47)$ & $3(18)$ & $1(6)$ & $12(71)$ & $5(29)$ & - & - \\
\hline LPHL (n, \%) & $1(20)$ & $4(80)$ & - & - & $5(100)$ & - & - & - \\
\hline & - & $1(33.3)$ & $1(33.3)$ & $1(33.3)$ & $2(67)$ & $1(33)$ & - & - \\
\hline \multicolumn{9}{|l|}{ Non-Hodgkin Lymphoma } \\
\hline $\operatorname{DLBCL}(\mathrm{n}, \%)$ & $10(19)$ & $30(55)$ & $9(17)$ & $5(9)$ & $39(72)$ & $15(28)$ & - & - \\
\hline$-\quad F L(n, \%)$ & & $1(25)$ & $3(75)$ & 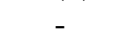 & $3(75)$ & $1(25)$ & - & - \\
\hline$-\operatorname{ALCL}(\mathrm{n}, \%) *$ & $2(50)$ & - & $1(25)$ & $1(25)$ & $3(75)$ & $1(25)$ & - & - \\
\hline$-\quad \operatorname{MZL}(n, \%)$ & - & $1(33)$ & $2(67)$ & - & $2(67)$ & $1(33)$ & - & - \\
\hline$-\quad \operatorname{MCL}(\mathrm{n}, \%)$ & - & $2(100)$ & - & - & $1(50)$ & $1(50)$ & - & - \\
\hline
\end{tabular}

*ALK negative

NSHL: Nodular Sclerosing Hodgkin Lymphoma, LPHL: Lymphocyte Predominant Hodgkin Lymphoma, FL: Follicular Lymphoma,

MZL: Marginal Zone Lymphoma,
MCHL: Mixed Cellularity Hodgkin Lymphoma, DLBCL: Diffuse Large B-cell Lymphoma, ALCL: Anaplastic Large Cell Lymphoma, MCL: Mantle Cell Lymphoma 
Table 1: The laboratory, clinical characteristics and PD-1/PD-L2 immunostaining results of the patients

\begin{tabular}{|c|c|c|}
\hline Characteristics & $\begin{array}{c}\text { Hodgkin Lymphoma } \\
\qquad(\mathrm{n}=25)\end{array}$ & $\begin{array}{l}\text { Non-Hodgkin Lymphoma } \\
\qquad(\mathrm{n}=67)\end{array}$ \\
\hline Age* & $38(15-80)$ & $65(19-87)$ \\
\hline Gender (female/male) & $13 / 12$ & $27 / 40$ \\
\hline $\mathrm{Hb}(\mathrm{g} / \mathrm{dL})^{*}$ & $11.7(8.5-15.6)$ & $12.3(7-16)$ \\
\hline WBC $\left(\times 10^{9} / \mathrm{L}\right)^{*}$ & $8.4(2.3-15.9)$ & $8.71(1-161)$ \\
\hline $\operatorname{PLT}\left(\times 10^{9} / \mathrm{L}\right) *$ & $320(102-608)$ & $248(10-918)$ \\
\hline $\mathrm{LDH}(\mathrm{IU} / \mathrm{L})^{*}$ & $256(139-518)$ & $308(141-6044)$ \\
\hline B symptoms ${ }^{+}, \mathrm{n}(\%)$ & $6(24)$ & $12(18.5)$ \\
\hline \multicolumn{3}{|l|}{ Disease stage, $\mathrm{n}(\%)^{* *}$} \\
\hline \multirow{4}{*}{$\begin{array}{ll}- & \text { Stage I } \\
- & \text { Stage II } \\
- & \text { Stage III } \\
- & \text { Stage IV }\end{array}$} & $3(12)$ & $8(11.9)$ \\
\hline & $11(44)$ & $24(35.8)$ \\
\hline & $9(36)$ & $19(28.4)$ \\
\hline & $2(8)$ & $16(23.9)$ \\
\hline \multicolumn{3}{|l|}{ IPI } \\
\hline - $\quad 0$ points & - & $3(4.5)$ \\
\hline - 1 points & - & $10(14.9)$ \\
\hline - $\quad 2$ points & - & $14(20.9)$ \\
\hline - 4 points & - & $20(29.9)$ \\
\hline \multirow[t]{2}{*}{ - $\quad 5$ points } & - & $17(25.4)$ \\
\hline & - & $3(4.5)$ \\
\hline \multirow[t]{5}{*}{ Subtypes, n (\%) } & NSHL: 17 (68) & DLBCL: 54 (80.6) \\
\hline & MCHL: 5 (20) & FL: 4 (6) \\
\hline & LPHL: 3 (12) & ALCL: 4 (6) \\
\hline & & MZL: 3 (4.5) \\
\hline & & MCL: 2 (3) \\
\hline \multicolumn{3}{|l|}{ PD-1 expression rate } \\
\hline$-\quad 0$ & $6(24)$ & $12(17.9)$ \\
\hline-1 & $13(52)$ & $34(50.7)$ \\
\hline $\begin{array}{l}-\quad 2 \\
-\quad 3\end{array}$ & $4(16)$ & $15(22.4)$ \\
\hline & $2(8)$ & $6(9)$ \\
\hline \multicolumn{3}{|l|}{ PD-L2 expression rate } \\
\hline$-\quad 0$ & $19(76)$ & $48(71.6)$ \\
\hline $\begin{array}{ll}- & 1 \\
- & 1\end{array}$ & $6(24)$ & $19(28.4)$ \\
\hline $\begin{array}{ll}- & 2 \\
- & 3\end{array}$ & - & - \\
\hline & - & - \\
\hline
\end{tabular}

* median (range), ** Ann Arbor disease staging,

Hb: Hemoglobin, WBC: White Blood Cell, PLT: Platelets, LDH: lactate dehydrogenase,

IPI: International Prognostic Index NSHL: Nodular Sclerosing Hodgkin Lymphoma,

MCHL: Mixed Cellularity Hodgkin Lymphoma, LPHL: Lymphocyte Predominant Hodgkin Lymphoma,

DLBCL: Diffuse Large B-cell Lymphoma, $\quad$ FL: Follicular Lymphoma,

ALCL: Anaplastic Large Cell Lymphoma, $\quad$ MZL: Marginal Zone Lymphoma,

MCL: Mantle Cell Lymphoma. 


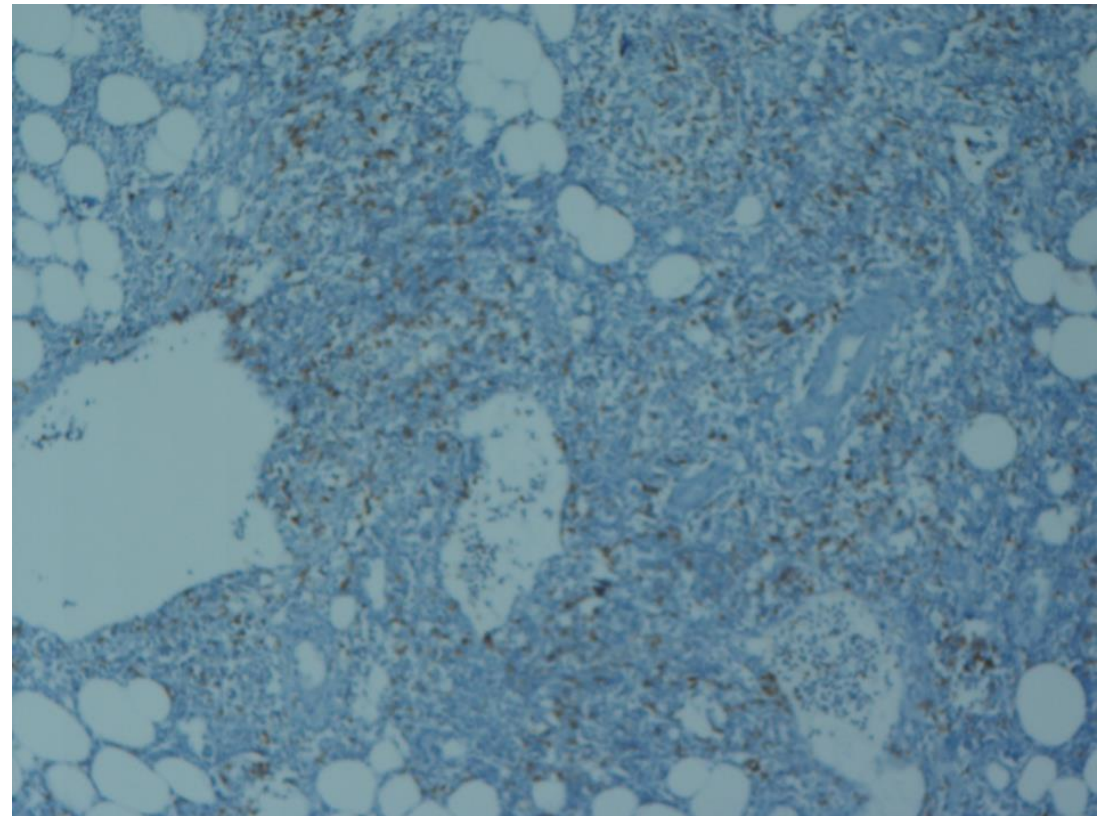

Fig 2: A representative image showing 1+ cytoplasmic-membranous staining of PD-L2 antibody (original magnification, $\mathrm{x} 10$ )

Of the patients, 23 out of 25 were alive in $\mathrm{HL}$ group. However, in NHL group, 31 out of 67 had died of disease progression or unrelated causes. The median overall survival (OS) was 64 months (HR: 49.82-78.19; 95\% CI) and 43 months (HR: $34.28-52.22 ; 95 \% \mathrm{CI})$ in HL and NHL groups, respectively. Since we have evaluated whether there is a correlation between IHC results and survival of patients with HL and NHL, there was no significance between PD-1 / PD-L2 expression rates and $\mathrm{HL}(\mathrm{p}=0.959 / \mathrm{p}=0.496)$ and NHL $(\mathrm{p}=0.946 / \mathrm{p}=0.217)$. Overall survival curves comparing PD-1 / PD-L2 expression rates and survival of patients with HL and NHL were displayed in figures $3,4,5$, and 6 , respectively. Also, we couldn't demonstrate a correlation between PD-1 / PD-L2 expression rates and International Prognostic Index (IPI) $(\mathrm{p}=0.533 /$ $\mathrm{p}=0.422$ ) in NHL group. And, there was no correlation between PD-1 / PD-L2 expression rates and disease stage in HL $(\mathrm{p}=0.921 / \mathrm{p}=0.118)$ and disease stage in NHL ( $\mathrm{p}=0.710 / \mathrm{p}=0.160)$.

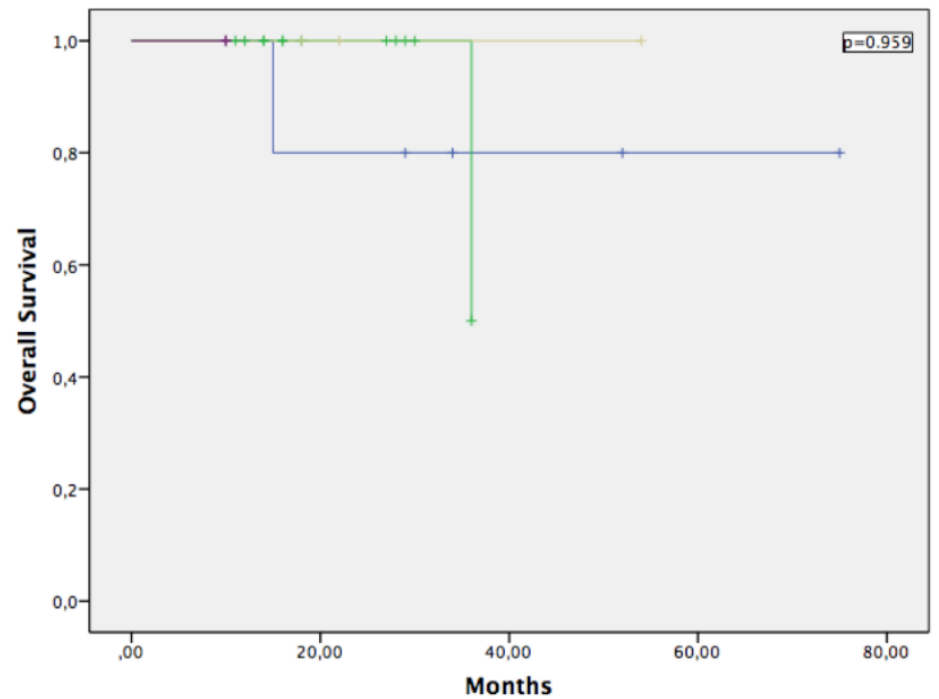

Fig 3: The survival of Hodgkin Lymphoma patients according to the expression of PD-1. 


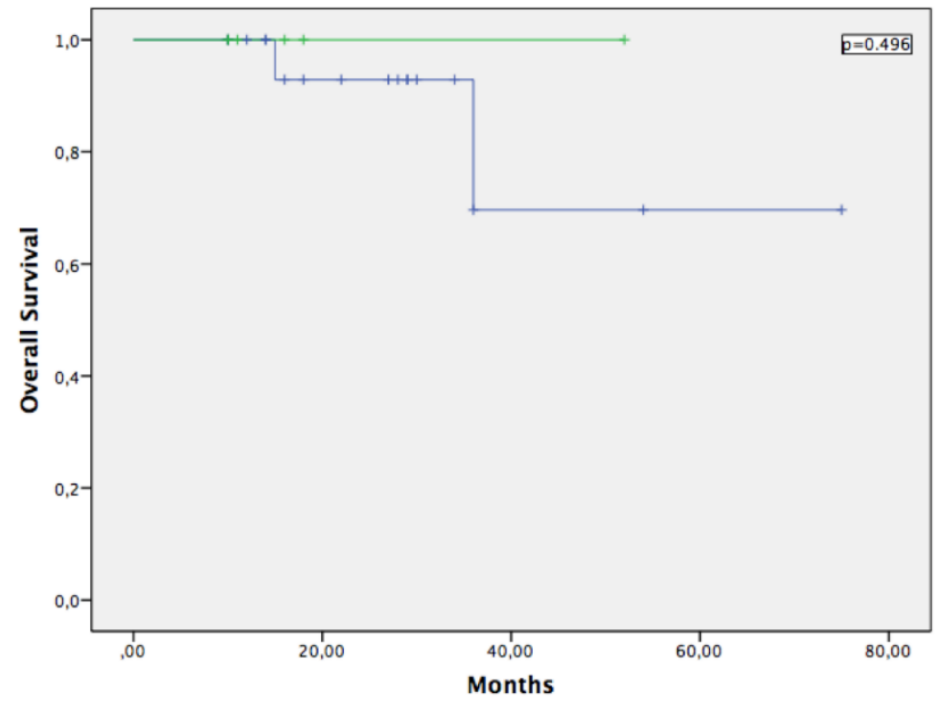

Fig 4: The survival of Hodgkin Lymphoma patients according to the expression of PD-L2

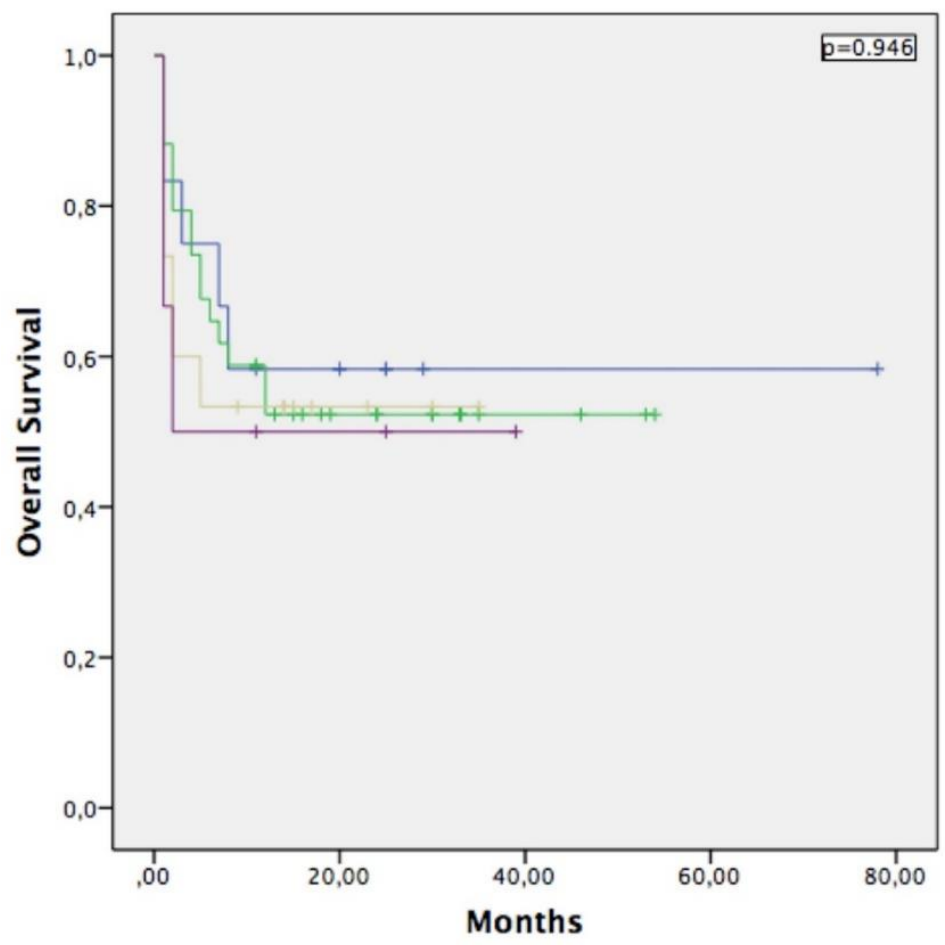

Fig 5: The survival of non-Hodgkin Lymphoma patients according to the expression of PD-1 


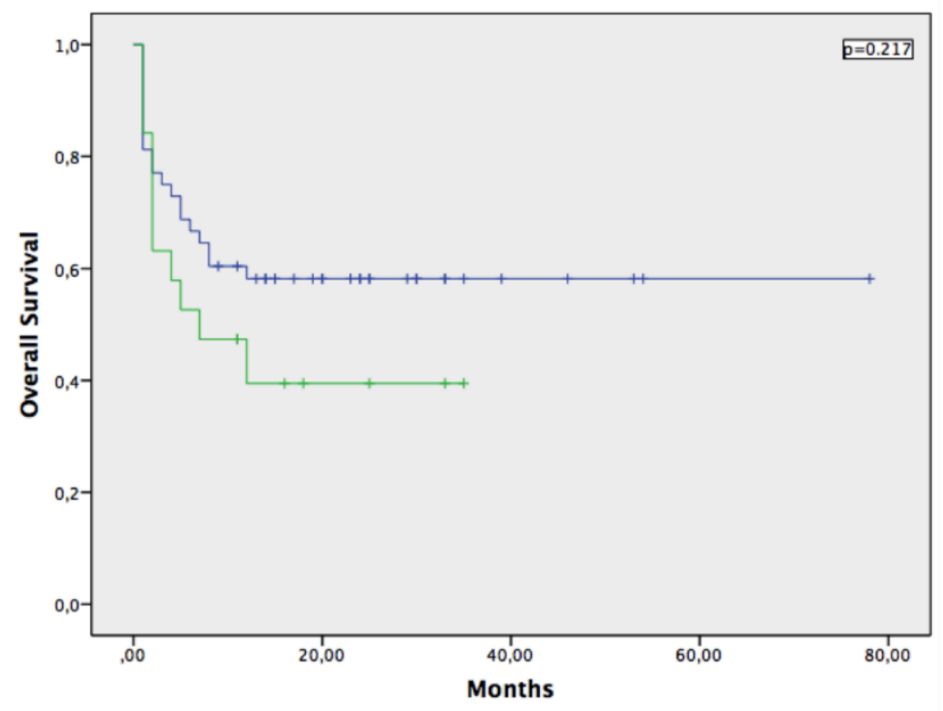

Fig 6: The survival of non-Hodgkin Lymphoma patients according to the expression of PD-L2

\section{DISCUSSION}

The PD-1 pathway plays a significant role in regulation of $\mathrm{T}$-cell activation and in apoptotic pathways of effector/memory T lymphocytes. The upregulation of PD-1 and PD-L1 may be a common phenomenon in lymphomas. Increasing data have shown that PD-1 is expressed at a higher level in T cells from tumor patients ${ }^{13}$. Tumor cells upregulate PD-L1 or PD-L2 to dampen this T lymphocyte attack. Binding of the PD-1 receptor with PD-L1 blocks phosphatidylinositol 3-kinase activation thus leading to down-regulation of stimulatory proteins required for T-cell proliferatio ${ }^{14,15}$. The checkpoint inhibition by tumor cells via the PD-1 pathway suppress the antitumor immune response. Tumor-associated immune suppression can lead to defective T-cell-mediated antitumor immunity and disease progression.

The role of PD-1 pathway has been extensively investigated in non-hematologic malignancies, however, it is not clear in hematologic malignancies. Expression of PD-L1 and PD-L2, has been identified both on tumor cells and within the tumor microenvironment. Some evidence have been found in HL and NHL, including both B-cell and T-cell subtypes ${ }^{6,8,16}$. It has been shown that PD-L1 is up-regulated on HL cells, and PD-1 is markedly elevated in the tumor-infiltrating or peripheral $\mathrm{T}$ cells of $\mathrm{HL}$ patients ${ }^{6}$. And also, PDL2 is upregulated primarily on primary mediastinal B-cell lymphoma, FL and HL [12]. PD-1 expression in NHL has been described in small lymphocytic lymphoma/chronic lymphocytic leukemia, FL, DLBCL, primary mediastinal B-cell lymphoma, anaplastic large-cell lymphoma, and angioimmunoblastic T-cell lymphoma $8,12,17$. In our study, the overall expression rate of PD-1 was 76\% and $82.1 \%$ in patients with HL and NHL, respectively. Nodular sclerosing subtype in HL group and DLBCL in NHL group expressed PD-1 much more than the other subtypes. These results may be the reflection of the frequency of subtypes in each group, because nodular sclerosing subtype $(68 \%)$ in HL group and DLBCL $(80.6 \%)$ in NHL group was the most frequent subtypes. Also, we have detected considerable PD-1 expression rates in other subtypes, however the number of patients were limited to make a clear decision. Another important finding of our study was the weak PDL2 expression rate in both HL and NHL cases, and majority of these cases didn't express PD-L2.

PD-1 expression has been explored as a potential predictor of prognosis, for hematologic malignancies, particularly lymphomas. The association of PD-1 expression and clinical outcomes has been variable across tumor subtypes. Muenst et al. have shown that the expression of PD-1 by classical HL is a stage-independent negative prognostic factor for $\mathrm{OS}{ }^{18}$. One retrospective study in FL showed that PD-1 positivity was an independent poor prognostic factor ${ }^{19}$, but another study in FL found that PD-1 positivity on tumor-infiltrating lymphocytes was associated with improvements in progression-free survival (PFS) and OS ${ }^{20}$. In our study, PD-1 and/or PD-L2 expression didn't demostrate a survival advantage or disadvantage in both lymphomas. Our results showed that there may be heterogeneity of 
PD-1 and/or PD-L2 expression even within specific lymphoma subtypes.

As it known, the confirmation of PD-1 or PD-L1 or PD-L2 expression by IHC staining is not required for clinical trial enrollment for hematologic malignancies. However, it's being done in solid tumor trials, routinely. For example; in a phase I nivolumab trial, IHC analysis on pretreatment tumor samples revealed that patients with PD-L1 positive ( $\geq 5 \%$ tumor cells with PD-L1 expression) tumor specimens had an excellent $36 \%$ objective response rate (ORR), on the contrary, patients with PD-L1 negative tumor specimens did not have any objective response ${ }^{11}$. Taube et al. reported on the analysis of 68 tumor samples that PDL1 expression, as a single factor, showed the strongest association with response to anti-PD1 therapy ${ }^{21}$. However, in a randomized, multicentric, phase 3 study that compared nivolumab monotherapy with docetaxel monotherapy in patients with advanced non-small-cell lung cancer, authors found that the PD-L1 expression was neither prognostic nor predictive of therapeutic benefit ${ }^{22}$.

Manipulation of the PD-1 pathway continues to be an area of great interest as a strategy. The administration of antibodies which interrupt interactions between negative regulatory receptors on tumor-specific $\mathrm{T}$ cells and their ligands on tumor cells has resulted in impressive clinical activity in some of human cancers ${ }^{23}$. The use of anti-PD-1 therapy in hematologic malignancies is limited to early-phase clinical trials. Ansell et al. have conducted a phase I study of nivolumab in patients with heavily pretreated relapsing or refractory classic HL [24]. They have shown an ORR as high as $87 \%$ (20 out of 23) including $17 \%$ complete responses and a PFS rate at 24 weeks of $86 \%$. In this study, infiltrating $\mathrm{T}$ cells in the available HL biopsy specimens largely expressed low levels of the PD-1 receptors, and tumor analysis from 10 patients confirmed increased expression of PD-L1 and PD-L2 in all samples ${ }^{24}$. Also, previous studies suggested that checkpoint blockers may be beneficial in various forms of NHL ${ }^{25,26}$. On the other hand, data on the role of anti-PD-1 therapy in other NHL subtypes are quite limited.

The results of this study are subjected to some limitations. First, this study is a single-center study with a relatively small sample size, which might underestimate or overestimate the results. Second, we have performed IHC staining on pretreatment biopsy materials, so we don't know if PD-1 and/or PD-L2 expression rate might change after anti-PD1 therapies. Third, because we couldn't provide the
PD-L1 immunostain, so we couldn't evaluate the expression rate of PD-L1 in our specimens.

In conclusion, IHC staining is a widespread method, easy to perform and cost-effective. We conclude that the role of PD-1 pathway can be demonstrated by IHC. By the way, we need to say that most of IHC studies of PD-1, PD-L1 and PDL2 are performed on HL and NHL cell lines, and also these are all limited in number. Furthermore, in the literature, it may be emphasized that the number of IHC studies on real life setting are very limited. In this context, we have made a study on patient lymph node specimens showing the expression rates of PD-1 and PD-L2 in various lymphoma subtypes, however we couldn't demonstrate a meaningful evidence that these markers have an impact on prognosis. More specifically designed prospective studies are needed to externally cross-validate our findings in a larger cohort of lymphoma patients. If IHC markers might be standardized in the future, especially a cutoff that defines a clinically significant positive and predictive value, may help identifying patients more likely to benefit from anti-PD-1 therapies.

\section{REFERENCES}

1. Topalian SL, Drake CG, Pardoll DM. Targeting the PD-1/B7-H1 (PD-L1) pathway to activate anti-tumor immunity. Curr Opin Immunol 2012;24:207-12.

2. Pardoll DM. The blockade of immune checkpoints in cancer immunotherapy. Nat Rev Cancer 2012;12:252-64.

3. Butte MJ, Keir ME, Phamduy TB, Sharpe AH, Freeman GJ. Programmed death-1 ligand 1 interacts specifically with the B7-1 costimulatory molecule to inhibit $\mathrm{T}$ cell responses. Immunity 2007;27:111-22.

4. Francisco LM, Salinas VH, Brown KE, Vanguri VK, Freeman GJ, Kuchroo VK, et al. PD-L1 regulates the development, maintenance, and function of induced regulatory $\mathrm{T}$ cells. J Exp Med 2009;206:3015-29.

5. Zou W, Chen L. Inhibitory B7-family molecules in the tumour micro environment. Nat Rev Immunol 2008;8:467-77.

6. Yamamoto R, Nishikori M, Kitawaki T, Sakai T, Hishizawa M, Tashima M, et al. PD-1-PD-1 ligand interaction contributes to immunosuppressive microenvironment of Hodgkin lymphoma. Blood 2008;111:3220-4.

7. Kozako $T$, Yoshimitsu $M$, Fujiwara $H$, Masamoto I, Horai S, White Y, et al. PD-1/PD- 
L1 expression in human T-cell leukemia virüs type 1 carriers and adult T-cell leukemia/lymphoma patients. Leukemia 2009;23:375-82.

8. Xerri L, Chetaille B, Serriari N, Attias C, Guillaume Y, Arnoulet C, et al. Programmed death 1 is a marker of angioimmunoblastic Tcell lymphoma and B-cell small lymphocytic lymphoma/chronic lymphocytic leukemia. Hum Pathol 2008;39:1050-8.

9. Wilcox RA, Feldman AL, Wada DA, Yang ZZ, Comfere NI, Dong H, et al. B7-H1 (PD-L1, CD274) suppresses host immunity in T-cell lymphoproliferative disorders. Blood 2009;114:2149-58.

10. Andorsky DJ, Yamada RE, Said J, Pinkus GS, Betting DJ, Timmerman JM. Programmed death ligand 1 is expressed by non-hodgkin lymphomas and inhibits the activity of tumorassociated $\mathrm{T}$ cells. Clin Cancer Res 2011;17:4232-44.

11. Topalian SL, Hodi FS, Brahmer JR, Gettinger SN, Smith DC, Mcdermott DF, et al. Safety, activity, and immune correlates of anti-PD-1 antibody in cancer. $\mathrm{N}$ Engl $\mathrm{J}$ Med 2012;366:2443-54.

12. Rosenwald A, Wright G, Leroy K, Yu X, Gaulard P, Gascoyne RD, et al. Molecular diagnosis of primary mediastinal B cell lymphoma identifies a clinically favorable subgroup of diffuse large B cell lymphoma related to Hodgkin lymphoma. J Exp Med 2003; 198:851-62.

13. Ribas A. Tumor immunotherapy directed at PD1. N Engl J Med 2012;366:2517-9.

14. Keir ME, Butte MJ, Freeman GJ, Sharpe AH. PD-1 and its ligands in tolerance and immunity. Annu Rev Immunol 2008;26:677-704.

15. Okazaki T, Honjo T. The PD-1-PD-L pathway in immunological tolerance. Trends Immunol 2006;27:195-201.

16. Liang SC, Latchman YE, Buhlmann JE, Tomczak MF, Horwitz BH, Freeman GJ, et al. Regulation of PD-1, PD-L1, and PD-L2 expression during normal and autoimmune responses. Eur J Immunol 2003;33:2706-16.

17. Dorfman DM, Brown JA, Shahsafaei A, Freeman GJ. Programmed death-1 (PD-1) is a marker of germinal center-associated $\mathrm{T}$ cells and angioimmunoblastic T-cell lymphoma. Am J Surg Pathol 2006;30:802-10.
18. Muenst S, Hoeller S, Dirnhofer S, Tzankov A. Increased programmed death-1+ tumorinfiltrating lymphocytes in classical Hodgkin lymphoma substantiate reduced overall survival. Hum Pathol 2009;40:1715-22.

19. Richendollar BG, Pohlman B, Elson P, Hsi ED. Follicular programmed death 1-positive lymphocytes in the tumor microenvironment are an independent prognostic factor in follicular lymphoma. Hum Pathol 2011;42:5527.

20. Carreras J, Lopez-Guillermo A, Roncador G, Villamor N, Colomo L, Martinez A, et al. High numbers of tumor-infiltrating programmed cell death 1-positive regulatory lymphocytes are associated with improved overall survival in follicular lymphoma. $\mathrm{J}$ Clin Oncol 2009;27:1470-6.

21. Taube JM, Klein AP, Brahmer JR, Xu H, Pan $\mathrm{X}$, Kim JH, et al. Association of PD-1, PD-1 ligands, and other features of the tumor immune microenvironment with response to anti-PD-1 therapy. Clin Cancer Res 2014;20:5064-74.

22. Brahmer J, Reckamp KL, Baas P, Crinò L, Eberhardt WE, Poddubskaya E, et al. Nivolumab versus Docetaxel in Advanced Squamous-Cell Non-Small-Cell Lung Cancer. N Engl J Med 2015;373:123-35.

23. Topalian SL, Drake CG, Pardoll DM. Immune checkpoint blockade: a common denominator approach to cancer therapy. Cancer Cell 2015;27:450-61.

24. Ansell SM, Lesokhin AM, Borrello I, Halwani A, Scott EC, Gutierrez M, et al. PD-1 blockade with nivolumab in relapsed or refractory Hodgkin's lymphoma. N Engl J Med 2015;372:311-9.

25. Armand P, Nagler A, Weller EA, Devine SM, Avigan DE, Chen YB, et al. Disabling immune tolerance by programmed death-1 blockade with pidilizumab after autologous hematopoietic stem-cell transplantation for diffuse large B-cell lymphoma: results of an international phase II trial. J Clin Oncol 2013;31:4199-206.

26. Westin JR, Chu F, Zhang M, Fayad LE, Kwak LW, Fowler N, et al. Safety and activity of PD1 blockade by pidilizumab in combination with rituximab in patients with relapsed follicular lymphoma: a single group, open-label, phase 2 trial. Lancet Oncol 2014;15:69-77. 